Piotr Zamojski

Uniwersytet Gdański

E-MAIL: pedpz@ug.edu.p

\title{
Sprawozdanie z 4. kolokwium Sieci Badawczej „Solidarity in Diversity” 23-24 stycznia 2018, Gandawa, Belgia
}

Badawcza sieć „Solidarity in Diversity”, założona przez prof. Stijna Oosterlyncka (Uniwersytet w Antwerpii) i ufundowana przez Flandryjską Fundację Badawczą (FWO), od czerwca 2016 spotyka się dwa razy w roku. Celem tego międzynarodowego i multidyscyplinarnego konsorcjum jest konceptualizacja solidarności w społeczeństwach złożonych. Wyrosła ona z projektu DieGem', kierowanego również przez prof. Oosterlyncka, na który składało się ponad 20 case studies prowadzonych $\mathrm{w}$ najbardziej gęstych etnicznie i spauperyzowanych regionach Belgii, najczęściej przy użyciu zaangażowanych badań w działaniu.

Każde spotkanie konsorcjum ma półotwarty charakter i oprócz stałych członków sieci biorą w nich udział badacze zainteresowani danym aspektem głównego zagadnienia solidarności w różnorodności. Niektóre ze spotkań mają charakter tematyczny (wrześniowe spotkanie w Leuven dotyczyło kwestii krzyżowania się społecznych tożsamości i wykluczeń, tzw. intersectionality), niektóre natomiast zbierają po prostu najnowsze dokonania badawcze w zakresie solidarności oraz skupiają na pracy seminaryjnej.

Dwudniowe spotkanie w Gandawie poświęcone zostało 13 różnym wystąpieniom relacjonującym badania $\mathrm{w}$ różnych dyscyplinach (geografia społeczna, pedagogika, filozofia, praca socjalna, etnografia, architektura, urbanistyka, socjologia), o różnym stopniu zaawansowania (także na poziomie samej konceptualizacji badań), prowadzonych przez badaczy o różnym doświadczeniu (od doktorantów po profesorów). Format kolokwium zakładał 30-minutową prezentację (45 min w przypadku keynote speaker) oraz 20-minutową dyskusję. Podczas wszystkich spotkań wszystkie prezentacje

1

http://www.solidariteitdiversiteit.be/diegem_en.php 
mają plenarny charakter, ponieważ za każdym razem kolokwia mają charakter kameralny i nie gromadzą więcej niż 30 osób.

Każde ze spotkań odbywa się przynajmniej częściowo w miejscu znaczącym z perspektywy głównego zagadnienia badawczego konsorcjum. W przypadku Gandawy było to Centrum Sąsiedzkie Traffiek, umiejscowione w dzielnicy Brugse Poort, zamieszkiwanej przez belgijską klasę robotniczą, imigrantów tureckich i marokańskich, a także - ostatnio - rodziny młodych specjalistów aspirujących lub należących do klasy średniej. Traffiek jest wyjątkowym przedsięwzięciem prywatnym, założonym przez ludzi z anarchistyczną i skłotową przeszłością, którzy prowadzą ten ośrodek bez jakichkolwiek dotacji od miasta Gandawa czy rządu Belgii, utrzymując się wyłącznie z prowadzonej przy współpracy imigrantów oczekujących na decyzje administracyjne kawiarni, jadłodajni oraz sali konferencyjnej.

Poniższa relacja z merytorycznego wymiaru spotkania w Gandawie ma charakter wybiórczy i łączy ze sobą argumentację prezentowaną w referatach z wątkami, które pojawiały się jedynie w dyskusjach.

Cedric Goossens z Uniwersytetu w Gandawie zajął się problemem przemian w szkołach położonych w dzielnicach w przeważającej mierze zamieszkanych przez imigrantów. Wówczas, gdy taka dzielnica ulega procesom gentryfikacyjnym i w coraz większym stopniu zostaje zamieszkana przez reprezentantów klasy średniej, niektóre ze szkół próbują przyciągnąć dzieci tych rodzin. Co interesujące, stoi za tym publicznie formułowana argumentacja o chęci zapewnienia różnorodności społecznej szkoły i praktykowania solidarności społecznej. Szkoły te dokonują poważnych zmian koncepcyjnych, pedagogicznych (w kierunku progresywizmu) oraz wizerunkowych (tożsamościowych). Co istotne - jak twierdzi badacz - proces ten paradoksalnie wprowadza nowe nierówności, ponieważ szkoły zdają się rywalizować o przyciągnięcie uczniów z klasy średniej (których traktuje się jako dobro rzadkie), co wprost oznacza rywalizację w byciu bardziej różnorodnym społecznie i etnicznie oraz w byciu bardziej solidarnym. W ten sposób logika neoliberalizmu wchodzi do postaw solidarnościowych tylnymi drzwiami.

Elisabet Van Wymeersch z Uniwersytetu z Antwerpii prezentowała swoje analizy dotyczące fenomenu „Żyjących Ulic” (Living Streets). „Żyjące Ulice” to projekt społeczny polegający na oddaniu we władzę mieszkańców ulicy, przy której mieszkają na okres kilku tygodni. Projekt jest realizowany we współpracy z wieloma miastami w Belgii (dla przykładu w 2016 roku 18 ulic w różnych miastach zostało objętych tym programem). Mieszkańcy zapraszani są na spotkania, podczas których decydują, jak chcą żeby ich ulica wyglądała - mogą na przykład zdecydować o wstrzymaniu ruchu samochodowego na 
czas trwania projektu, zbudowaniu placu zabaw lub miejsca wspólnego piknikowania na środku swojej ulicy, czy też o pomalowaniu jej w jakiś szczególny sposób. Ten projekt urbanistyczny zakłada zatem defunkcjonalizację ulicy jako przestrzeni transportowej i nadanie jej innego znaczenia w toku deliberacji. $\mathrm{W}$ toku negocjacji $\mathrm{w}$ ramach różnych odsłon projektu narastają konflikty klasowe, które prowadzą do wycofania się przedstawicieli klasy robotniczej (którzy zazwyczaj żądają miejsca dla ruchu samochodowego) oraz klasy średniej (która chce przekształcenia ulicy w miejsce rekreacji).

Hilde Verschaeve z Centrum Sąsiedzkiego Traffiek w Gandawie prezentowała historię budowania tej instytucji. Wskazała, że jest to możliwe jedynie dzięki stałemu zaangażowaniu ludzi, którzy mogliby zostać uznani przez zewnętrznych obserwatorów za nieco szalonych, ale przede wszystkim ludzi dysponujących dużą ilością wolnego, nieopłaconego czasu pracy. Traffiek powstał dzięki osobom prywatnym, które pożyczały inicjatorom pieniądze na założenie tej instytucji w ramach umów cywilnoprawnych na okres 5, 10, lub 15 lat. Hilde podkreśliła znaczenie posiadania budynku, miejsca, które stanowi schronienie, społeczną wiarygodność i różnorodnie aktualizowaną potencjalność.

W dyskusji nad tą prezentacją Stijn Oosterlynck podkreślił, że solidarność tworzy się w odniesieniu do rzeczy wspólnych (na przykład wówczas, gdy ludzie wychodzą na „papierosa” i tworzą wspólne więzi). Być może należałoby poświęcić więcej energii na badanie znaczenia rzeczy w powoływaniu solidarności do życia.

Nick Schuermans (Wolny Uniwersytet w Brukseli) i Joke Vandenabeele (KULeuven) przedstawili badanie interakcji na szkolnym podwórku w superzróżnicowanej etnicznie i klasowo szkole. Badacze postawili sobie pytanie, jak uczniowie uczą się życia razem, które postanowili spenetrować dokonując etnograficznej obserwacji interakcji na szkolnym podwórku w jednej z brukselskich szkół. Do analizy danych użyli idei trzech funkcji edukacji Gerta Biesty (2010). Na podstawie wyników badań dokonali rozróżnienia na miękkie i polityczne formy solidarności (light and political forms of solidarity). Formy miękkie dotyczą troski o innych, dzielenia losu i czasu. Formy polityczne to podejmowanie kwestii nierówności, redystrybucji, uznania i reprezentacji. Badacze wskazali również na działanie „mniejszych pedagogii” (minor pedagogies), które nie są inicjowane przez jednego aktora (np. nauczyciela), ale przez wielu o różnych statusach.

Anna Wilson z Uniwersytetu Stirling prezentowała program commonfare.net, który jest wspierany grantem Europejskiej Rady Naukowej. Program polega na tworzeniu społeczności, które działałyby zgodnie $\mathrm{z}$ ideą common- 
fare (Fumagali, Lucarelli, 2015), czyli bez możliwości zadłużenia, spekulacji i bankowości. Jednym z głównych działań objętych projektem jest tworzenie kryptowaluty, która działałaby zgodnie z założeniami commonfare.

Martina Bovo z Politechniki w Mediolanie przedstawiła projekt receptywnego miasta, który ma na celu urbanistyczne przedefiniowanie integracji uchodźców oczekujących w mieście na azyl. Dotychczas uchodźcy lokowani są w prywatnie prowadzonych (i publicznie dotowanych) domach przejściowych, w których mogą przebywać przez określony czas. Domy te stanowią jedyną przestrzeń, w obrębie której uchodźcy otrzymują wszelką przewidzianą prawem pomoc, co prowadzi do swoistej gettoizacji tych miejsc oraz ich alienacji ztkanki miasta. Projekt polega na włączeniu istniejącej infrastruktury miasta w proces integracji (np. odbieranie bezpłatnej odzieży w lokalnych sklepach z używanymi ubraniami).

Jante Schmidt (Uniwersytet Studiów Humanistycznych w Utrechcie) przedstawiła swoje studia nad kwestią operacjonalizacji godności ludzi z różnorodnymi problemami. Model, nad którym pracuje odchodzi od substancjalnego pojęcia godności ludzkiej jako wewnętrznej właściwości człowieka i zajmuje się społecznym wymiarem godności. Godność jest wówczas definiowana w odniesieniu do upokorzenia/poniżenia (humiliation). Wskazano możliwe wymiary tak pojmowanej godności, które przejawiają się w traktowaniu danej osoby jako uczestniczącej, dorosłej, wyjątkowej i normalnej. W dyskusji nad tym referatem podkreślono kwestię relacyjnego charakteru godności ludzkich (możliwość jej dawania i odbierania przez innych ludzi) oraz postawiono pytanie o relację godności i honoru w rozumieniu kultury muzułmańskiej.

Diarmaid Kelliher z Uniwersytetu w Glasgow przedstawił referat dotyczący solidarności wśród i z górnikami brytyjskimi podczas strajków w latach 1984-1985. Z badań historyczno-biograficznych wyłania się trajektoria wieloletnich związków między różnymi grupami społecznymi (m.in. górnicy i środowiska LGBT), które wspierały się wzajemnie przez dekady. Kluczowe okazuje się zatem zaufanie wynikające z wierności sobie nawzajem we wspieraniu swoich spraw (żądań). Wierność ta (jako przeciwstawiona potencjalności zdrady) rodzi dług (w rozumieniu społecznym, a nie monetarnym), który kreuje między tymi grupami więź solidarności.

Jacek Kołtan z Europejskiego Centrum Solidarności przedstawił historię myślenia o solidarności w obrębie myślicieli z krajów Europy Wschodniej. Ewolucja tej myśli przebiegała od egzystencjalnego ujęcia solidarności (Jan Patočka) do ujęć politycznych (Vaclav Havel) aż do koncepcji etycznej (Józef Tischner). Równolegle do tej ewolucji przebiegała transformacja samego 
ruchu solidarności, który w odróżnieniu od zachodniego świata był związany nie $\mathrm{z}$ kwestiami państwa opiekuńczego, ale z walką o demokratyczne państwo prawa. Ta transformacja stoi dziś przed wyzwaniem rekonstrukcji solidarności wobec jej współcześnie dominujących przygodnych i nietrwałych form.

Całość kolokwium zakończyła dyskusja nad programem następnego spotkania sieci, które wyjątkowo odbędzie się poza Belgią, mianowicie w Gdańsku, przy współpracy Uniwersytetu Gdańskiego i Europejskiego Centrum Solidarności.

\section{BIBLIOGRAFIA}

Biesta, G.J.J. (2010). Good Education in the Age of Measurement. Ethics, Politics, Democracy. Paradigm Pub., Boulder - London.

Fumagali, A., Lucarelli, S. (2015). Finance, Austerity and Commonfare. Theory, Culture \& Society. 